Cite this: Dalton Trans., 2014, 43 10977

Received 22nd May 2014, Accepted 28th May 2014

DOI: $10.1039 / \mathrm{c} 4 \mathrm{dt} 01508 \mathrm{~h}$ www.rsc.org/dalton

\title{
A monomer-dimer nanoswitch that mimics the working principle of the SARS-CoV 3CLpro enzyme controls copper-catalysed cyclopropanation $\uparrow$
}

\author{
Soumen De, Susnata Pramanik and Michael Schmittel* \\ A triangular framework with a terpyridine and shielded phenanthroline at its termini constitutes an \\ open/close nanoswitch that is toggled by chemical inputs. In the presence of copper(I) ions, the open tri- \\ angular framework (OPEN-I) firmly closes to a catalytically inactive heteroleptic [Cu(phen)(terpy)] ${ }^{+}$ \\ complex (CLOSE). Reversible switching between CLOSE and OPEN-I states was demonstrated by succes- \\ sive addition and removal of $\mathrm{Cu}^{+}$. In contrast, after addition of iron(॥) ions to the CLOSE state a bishomo- \\ leptic dimeric $\left[\mathrm{Fe}(\text { terpy })_{2}\right]^{2+}$ complex is formed with the copper(I) ions placed in the phenanthroline \\ cavities (OPEN-II). Due to its coordinatively unsaturated $\left[\mathrm{Cu}(\text { Phen) }]^{+}\right.$sites the dimeric iron complex is able \\ to serve as a catalyst in the cyclopropanation of $Z$-cyclooctene using ethyl diazoacetate.
}

\section{Introduction}

The principles used by intricate biological machines to modulate their activity with supreme efficacy have become both an inspiration and aspiration for many researchers who want to design and investigate artificial molecular machines ${ }^{1}$ and switches. ${ }^{2}$ A particularly strong fascination arises from the smart management of pronounced translational and/or rotational motions that trigger useful functions due to the spatial rearrangement. ${ }^{3}$ Inspired by biological archetypes, very recently artificial nanoswitches have been introduced whose catalytic action is controlled through pronounced translational and/or rotational motions. ${ }^{4}$ In this context, triangular nano-frameworks have proven to be robust toggles for turning ON/OFF photo- and organocatalytic reactions in a fully reversible manner. ${ }^{5}$

Nature has been very imaginative to accomplish spectacular catalytic processes that up to now do not have any analogy in the abiological world. For example, the severe acute respiratory syndrome coronavirus (SARS-CoV) $3 \mathrm{C}$-like protease (3Clpro) ${ }^{6}$ is enzymatically active only as a homodimer. The monomeric enzyme is inactive as its catalytic machinery is frozen in the collapsed state. In the present work we describe the synthesis and operation of nanoswitch $\mathbf{1}$ that is designed to constitute

Center of Micro and Nanochemistry and Engineering, Organische Chemie I,

Universität Siegen, Adolf-Reichwein-Str. 2, D-57068 Siegen, Germany.

E-mail:schmittel@chemie.uni-siegen.de

$\dagger$ Electronic supplementary information (ESI) available: Full experimental procedures with assignment of ${ }^{1} \mathrm{H}$ NMR signals, spectra of compounds, documentation of catalysis. See DOI: 10.1039/c4dt01508h an active transition metal catalyst in its homodimeric form and to be inactive in the collapsed monomeric state. To the best of our knowledge such a protocol to toggle catalysis is without precedents.

For setting up an ON/OFF dimer/monomer toggle, we devised nanoswitch 1 (Scheme 1) based on a triangular geometry, because such a design has proven its utility in a convincing manner. ${ }^{5}$ Its function to undergo monomer-to-dimer switching was implemented by considering the coordination preferences of copper(I) and iron(II) ions. While $\mathrm{Cu}^{+}$prefers a tetrahedral coordination, $\mathrm{Fe}^{2+}$ is strongly inclined toward the octahedral setting. We expected to lock the switch upon addition of copper(I) ions and to reversibly convert $[\mathrm{Cu}(\mathbf{1})]^{+}$either to its starting state 1 by removal of copper ions (Scheme 1) or to its bishomoleptic "dimeric" state $\left.\left[\mathrm{Fe}(\mathrm{Cu}(\mathbf{1}))_{2}\right)\right]^{4+}$ by adding $\mathrm{Fe}\left(\mathrm{ClO}_{4}\right)_{2}$. The latter state should reverse to $[\mathrm{Cu}(\mathbf{1})]^{+}$by selective removal of $\mathrm{Fe}^{2+}$ in the presence of $\mathrm{Cu}^{+}$. We anticipated that the exposed copper site in the dimer is catalytically active (e.g. in a cyclopropanation reaction), which would allow us to mimic the overall working mode of the SARS-CoV 3C-like protease.

\section{Model study}

To assess in advance the chances for the proposed monomerto-dimer switching, we studied the self-sorting of the putative terminal ligands in the presence of both cations. ${ }^{7}$ When one equivalent of $\mathrm{Cu}^{+}$was added to a $1: 1$ mixture of 2,9-dimesitylphenanthroline (2) and terpyridine (3), the heteroleptic complex $[\mathrm{Cu}(2)(3)]^{+}(\log \beta=9.1)^{8}$ emerged exclusively as 


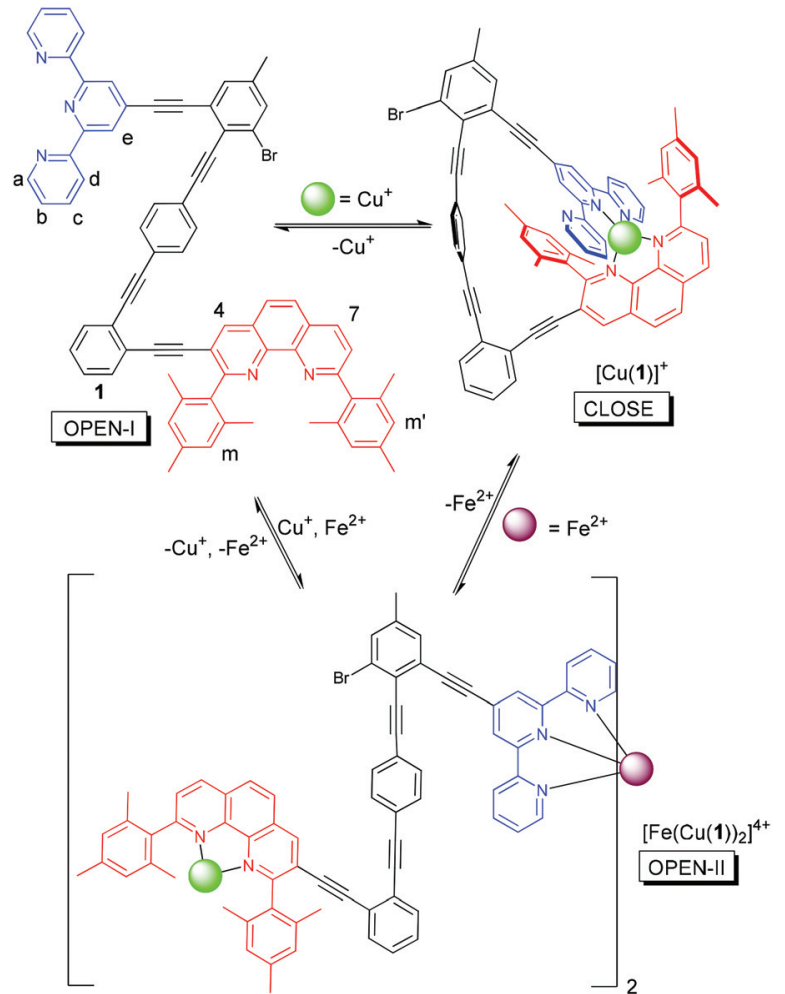

Scheme 1 Switching between close and two open forms of nanoswitch 1.

verified from the ${ }^{1} \mathrm{H}$ NMR data (Fig. S23, ESI $\dagger$ ). Upon addition of $\mathrm{Fe}^{2+}$ (0.5 equiv.) to $[\mathrm{Cu}(2)(3)]^{+}$, the heteroleptic complex completely vanished, while the bishomoleptic complex [Fe $\left.(3)_{2}\right]^{2+}(\log \beta=16.9)^{9}$ formed exclusively releasing the coordinatively unsaturated $[\mathrm{Cu}(2)]^{+}\left(\log K_{1}=5.1\right)$ (Fig. S24†) into solution (Scheme 2).

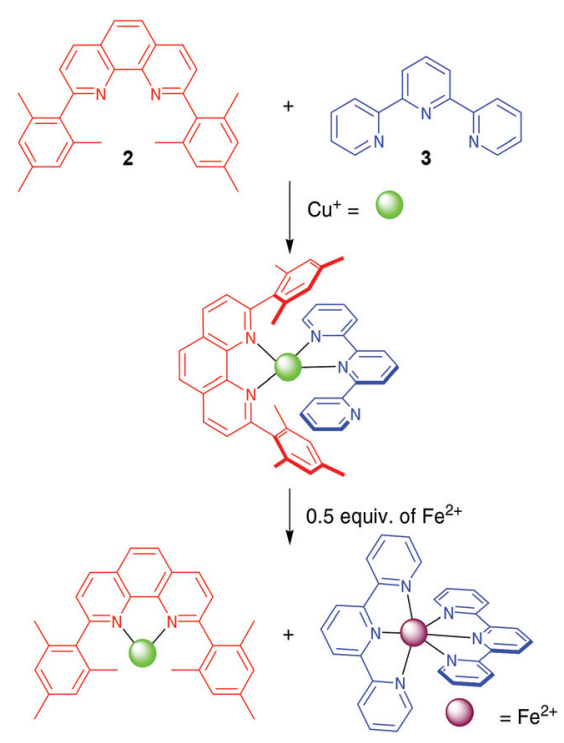

Scheme 2 Switching the coordination mode in model ligand scenarios depending on the metal ions.
The fully orthogonal coordination scenario in Scheme 2 suggested to integrate the respective ligands into the covalent triangular framework of nanoswitch $\mathbf{1}$ and to realise toggling between monomer and dimer states as a function of the added metal ions.

\section{Results and discussion}

\section{Synthesis}

The straightforward converging synthesis of nanoswitch 1 involves a series of Sonogashira couplings and deprotection steps. At first, 4-ethynylterpyridine was selectively coupled to one of the bromo substituents of compound 4 in a Sonogashira reaction using $\mathrm{Pd}\left(\mathrm{PPh}_{3}\right)_{4}$ in THF and triethylamine (TEA), then the TMS-protecting group was removed from compound 5 in the presence of aqueous $\mathrm{KOH}$ to afford terpyridine 6 (Scheme 3). In a similar way, 2,9-dimesityl-3-ethynyl $[1,10]$ phenanthroline (7) was reacted with (2-iodophenylethynyl)trimethylsilane in the presence of $\mathrm{Pd}\left(\mathrm{PPh}_{3}\right)_{4}$ to furnish 8 (Scheme 4). Finally, phenanthroline 10 was afforded by

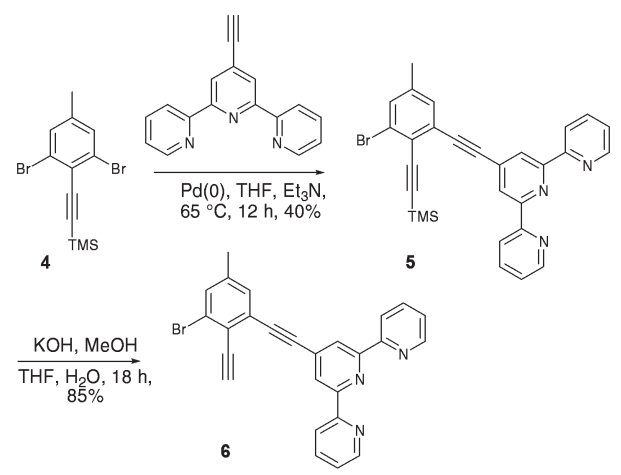

Scheme 3 Synthesis of terpyridine building block 6 .

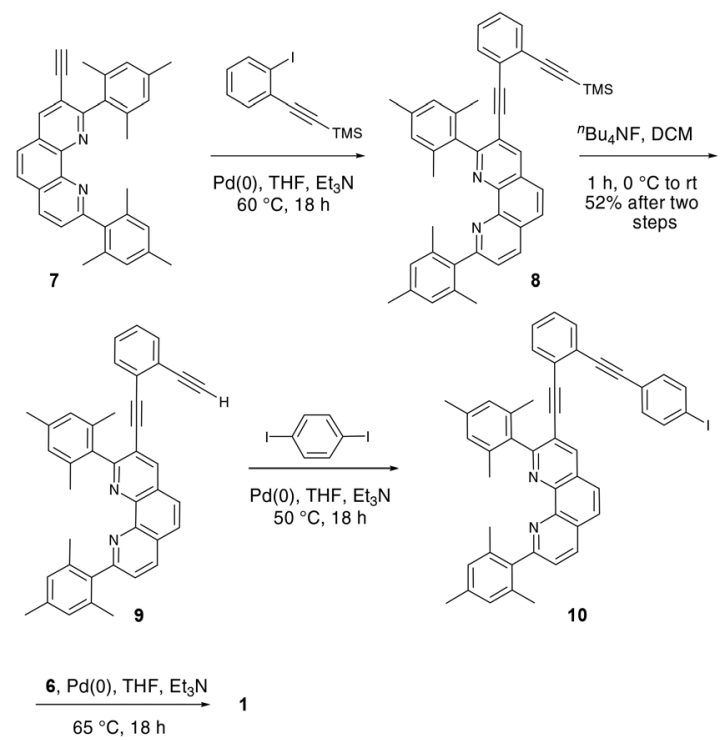

Scheme 4 Synthesis of nanoswitch 1. 
removing the TMS-protection group in the presence of aqueous $\mathrm{KOH}$ followed by reaction with 1,4-diiodobenzene in the presence of $\mathrm{Pd}\left(\mathrm{PPh}_{3}\right)_{4}$. Nanoswitch 1 was finally obtained in a Sonogashira coupling reaction between $\mathbf{6}$ and $\mathbf{1 0}$ in the presence of $\mathrm{Pd}\left(\mathrm{PPh}_{3}\right)_{4}$ as a catalyst in a THF-TEA mixture. Characterisation of the nanoswitch and of all other new compounds is described in detail in the experimental part and in the ESI. $\dagger$

\section{Switching studies}

At first, switching between open and close forms of 1 was probed using $\mathrm{Cu}^{+}$ions (Scheme 1). As expected, addition of one equivalent of $\left[\mathrm{Cu}\left(\mathrm{CH}_{3} \mathrm{CN}\right)_{4}\right] \mathrm{PF}_{6}$ to a solution of nanoswitch $1(0.10 \mathrm{mM})$ in $\mathrm{CD}_{2} \mathrm{Cl}_{2}$ resulted in significant shifts in the ${ }^{1} \mathrm{H}$ NMR spectrum. The diagnostic upfield shift of the signal for the aromatic mesityl protons from 6.95 and $6.97 \mathrm{ppm}$ (Fig. 1, bottom) to $4.48,5.89,6.28$, and $6.43 \mathrm{ppm}$ due to shielding from the terpyridine ring suggests the formation of the intramolecular complex $[\mathrm{Cu}(\mathbf{1})]^{+}$. Further support for this assignment was received from the simultaneous upfield shift of the terpyridine protons $\mathrm{a}-\mathrm{H}$ and $\mathrm{b}-\mathrm{H}$ from 8.68 and $7.25 \mathrm{ppm}$ to 6.66 and $6.78 \mathrm{ppm}$, respectively. Intramolecular complexation was further supported by the concentration independence of the ${ }^{1} \mathrm{H}$ NMR signals (Fig. S16 $\dagger$ ). Moreover, the ESI mass spectrum of the resulting complex shows a molecular ion peak at $m / z 1128.1$ (Fig. S31†) corresponding to the monomeric complex $[\mathrm{Cu}(\mathbf{1})]^{+}$. Its experimental isotopic distribution perfectly matches with the theoretical one. Thus, NMR and ESI-MS unanimously validate intramolecular complexation.

When $[\mathrm{Cu}(\mathbf{1})]^{+}$was treated with one equivalent of cyclam, the ${ }^{1} \mathrm{H}$ NMR peaks at 4.48, 5.89, 6.28, and 6.43 ppm disappeared, whereas the ${ }^{1} \mathrm{H}$ signals at 6.95 and $6.97 \mathrm{ppm}$ emerged, being diagnostic for nanoswitch 1 (Fig. S32 $\dagger$ ). These changes indicate that the system is fully set back to the open form with one equivalent of cyclam only. Quantitative multiple switching between OPEN-I and CLOSE was initiated by alternate additions of one equivalent of $\mathrm{Cu}^{+}$and one equivalent of cyclam for up to two cycles.

When 0.5 equiv. of $\mathrm{Fe}\left(\mathrm{ClO}_{4}\right)_{2}$ was added to nanoswitch 1 (OPEN-I), the homodimeric complex $\left[\mathrm{Fe}(\mathbf{1})_{2}\right]^{2+}$ formed by using exclusively the terminal terpyridine unit for complexation. This choice is driven by the strong preference of $\mathrm{Fe}^{2+}$ for hexacoordination, as even visually perceptible from a distinct colour change from light yellow to deep violet. Concordantly, the ${ }^{1} \mathrm{H}$ NMR spectrum shows the expected shifts of the terpyridine protons after iron complex formation (Fig. 2, top).

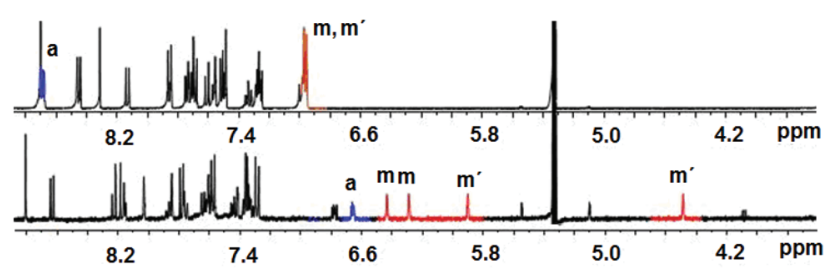

Fig. $1{ }^{1} \mathrm{H}$ NMR (400 MHz, $\mathrm{CD}_{2} \mathrm{Cl}_{2}, 298 \mathrm{~K}$ ) of switch 1 (top) and [Cu(1)] ${ }^{+}$ (bottom).

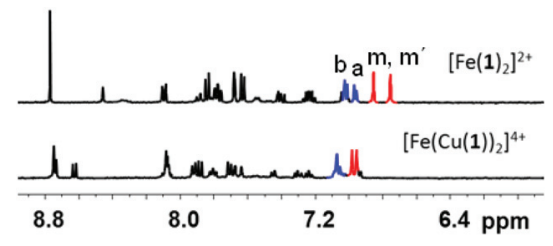

Fig. $2{ }^{1} \mathrm{H}$ NMR (400 MHz, $\mathrm{CD}_{2} \mathrm{Cl}_{2}, 298 \mathrm{~K}$ ) of (top) $[\mathrm{Fe}(1)]^{2+}$ and (bottom) $\left[\mathrm{Fe}(\mathrm{Cu}(1))_{2}\right]^{4+}$.

The terpyridine a-H protons shift upfield from 8.68 to $6.96 \mathrm{ppm}$, protons b-H from 7.25 to $7.01 \mathrm{ppm}$, and protons $\mathrm{d}-\mathrm{H}$ from 8.45 to $8.09 \mathrm{ppm}$. Protons e- $\mathrm{H}$, in contrast, shift slightly downfield from 8.70 to 8.77 ppm. Summing up, the diagnostic changes in the ${ }^{1} \mathrm{H}$ NMR signals unambiguously support formation of $\left[\mathrm{Fe}(\mathbf{1})_{2}\right]^{2+}$.

To evaluate the coordination preference of both metal ions in a competitive scenario, we added 2.0 equiv. of $\mathrm{Cu}^{+}$to the above solution of $\left[\mathrm{Fe}(\mathbf{1})_{2}\right]^{2+}$. The ${ }^{1} \mathrm{H}$ NMR was fully consistent with the formation of $\left[\mathrm{Fe}(\mathrm{Cu}(\mathbf{1}))_{2}\right]^{4+}$ with the copper(I) ions placed in both phenanthroline binding sites (OPEN-II). Diagnostically, the mesityl protons at 6.75 and $6.85 \mathrm{ppm}$ of $\left[\mathrm{Fe}(\mathbf{1})_{2}\right]^{2+}$ (Fig. 2, top) are now shifted downfield to 6.95 and 6.96 ppm (Fig. 2, bottom). Similarly, the downfield shifts of phenanthroline protons $4-\mathrm{H}$ and $7-\mathrm{H}$ from 8.45 and $8.09 \mathrm{ppm}$ to 8.73 and $8.62 \mathrm{ppm}$, respectively, confirm the existence of $\mathrm{Cu}^{+}$-loaded phenanthroline sites. Actually, the metal ions are occupying the same ligand sites as in the simple model system (Scheme 2). Exactly the same ${ }^{1} \mathrm{H}$ NMR spectrum was obtained (Fig. S17†) upon addition of 0.5 equivalent of $\mathrm{Fe}\left(\mathrm{ClO}_{4}\right)_{2}$ to the closed nanoswitch $[\mathrm{Cu}(\mathbf{1})]^{+}$(CLOSE) suggesting quantitative switching to the dimeric $\left[\mathrm{Fe}(\mathrm{Cu}(\mathbf{1}))_{2}\right]^{4+}$ (OPEN-II).

Reversible switching between OPEN-II and CLOSE states was accomplished by selective removal of $\mathrm{Fe}^{2+}$. After addition of 4-N,N-dimethylaminoterpyridine to $\left[\mathrm{Fe}(\mathrm{Cu}(\mathbf{1}))_{2}\right]^{4+}(\mathrm{OPEN}-\mathrm{II})$, a very strong known complexing agent for $\mathrm{Fe}^{2+}$ ions, we observed the clean formation of CLOSE and $[\mathrm{Fe}(4-N, N-$ dimethylaminoterpyridine $\left.)_{2}\right]^{2+}$. The closed form $[\mathrm{Cu}(\mathbf{1})]^{+}$was identified by its mesityl protons that diagnostically reappear at 4.48, 5.89, 6.28, and $6.43 \mathrm{ppm}$ in the ${ }^{1} \mathrm{H}$ NMR spectrum (Fig. S33†). The above observation is also consistent with a model study: when two equivalents of $4-\mathrm{N}, \mathrm{N}$-dimethylaminoterpyridine were added to a $2: 1$ mixture of model complexes $[\mathrm{Cu}(2)]^{+}$and $\left[\mathrm{Fe}(3)_{2}\right]^{2+}$, the $\mathrm{Fe}^{2+}$ ions were selectively removed from complex $\left[\mathrm{Fe}(3)_{2}\right]^{2+}$ to generate $[\mathrm{Cu}(2)(3)]^{+}$. Importantly, reversible nanoswitching between monomer and dimer was successfully accomplished for up to two cycles (Fig. S33†).

\section{Catalysis}

After the successful implementation of the monomer-to-dimer switching process, we investigated the efficacy of the nanoswitch to act as a switchable transition metal catalyst. Cyclopropanation of $Z$-cyclooctene (11) with ethyldiazoacetate (12) is a prototypical reaction accelerated by $\mathrm{Cu}^{+}$ions (Scheme 5). 


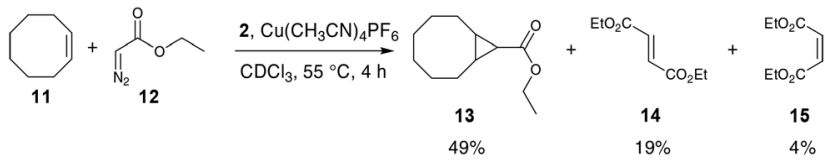

Scheme 5 Catalytic reaction used in the present study.

We first confirmed that the reaction between 11 and $\mathbf{1 2}$ $(1: 1)$ does not proceed in the presence of complex ${ }^{10}[\mathrm{Cu}(2)$ $([1,10]$-phenanthroline $)]^{+}(10 \mathrm{~mol} \%)$ (Fig. S36†), whereas the coordinatively frustrated $[\mathrm{Cu}(2)]^{+}$complex $(10 \mathrm{~mol} \%$ ) catalyses the formation of the cyclopropane 13 in $49 \pm 4 \%$ yield $\left(55^{\circ} \mathrm{C}\right.$, $4 \mathrm{~h}$ ) while forming the known decomposition products 14 and 15 (Fig. S35†). A control experiment in the presence of $\mathrm{Cu}^{+}$ alone produced $30 \pm 4 \%$ of the product 13 (Fig. S34†).

When a $1: 1$ mixture of $\mathbf{1 1}$ and $\mathbf{1 2}$ was heated in the presence of $10 \mathrm{~mol} \%$ of nanoswitch $[\mathrm{Cu}(\mathbf{1})]^{+}(0.10 \mathrm{mM})=$ CLOSE in an NMR tube at $55{ }^{\circ} \mathrm{C}$ for $4 \mathrm{~h}$, no cycloaddition product was observed as evidenced from the ${ }^{1} \mathrm{H}$ NMR spectrum (Fig. 3a). However, when the same experiment was performed under the same conditions with the help of dimer $\left[\mathrm{Fe}(\mathrm{Cu}(\mathbf{1}))_{2}\right]^{4+}$ $(0.10 \mathrm{mM}, 10 \mathrm{~mol} \%)=$ OPEN-II, $35 \pm 3 \%$ of cyclopropane 13 was afforded (Fig. 3b).

Finally, the in situ OFF/ON switching of catalysis was executed. As before, the closed form of nanoswitch $1=$ CLOSE did not afford any cyclopropanation product 13 (Fig. S37†). After addition of 0.5 equivalent of $\mathrm{Fe}\left(\mathrm{ClO}_{4}\right)_{2}$ to this very mixture and heating at $55{ }^{\circ} \mathrm{C}$ for $4 \mathrm{~h}$, the cyclopropane 13 emerged in $30 \pm$ $5 \%$ yield (Fig. S37†).

A further control experiment was performed, now with homodimer $\left[\mathrm{Fe}(\mathbf{1})_{2}\right]^{2+}$, to check whether the iron homodimeric residue is responsible for catalysis. After adding 0.5 equiv. of $\mathrm{Fe}\left(\mathrm{ClO}_{4}\right)_{2}$ to nanoswitch $\mathbf{1}$, the thus prepared $\left[\mathrm{Fe}(\mathbf{1})_{2}\right]^{2+}$ was exposed to a 1:1 mixture of $\mathbf{1 1}$ and $\mathbf{1 2}$ under the same conditions as for catalysis. No cyclopropanation occurred (Fig. S38 $\dagger$ )! Catalytic activity returned, though, after further addition of two equivalents of $\mathrm{Cu}^{+}$to $\left[\mathrm{Fe}(\mathbf{1})_{2}\right]^{2+}$ furnishing dimer $\left[\mathrm{Fe}(\mathrm{Cu}(\mathbf{1}))_{2}\right]^{4+}$. Now cyclopropane 13 was formed in $30 \pm$ $5 \%$ yield after heating the reaction mixture for $4 \mathrm{~h}$ at $55^{\circ} \mathrm{C}$.

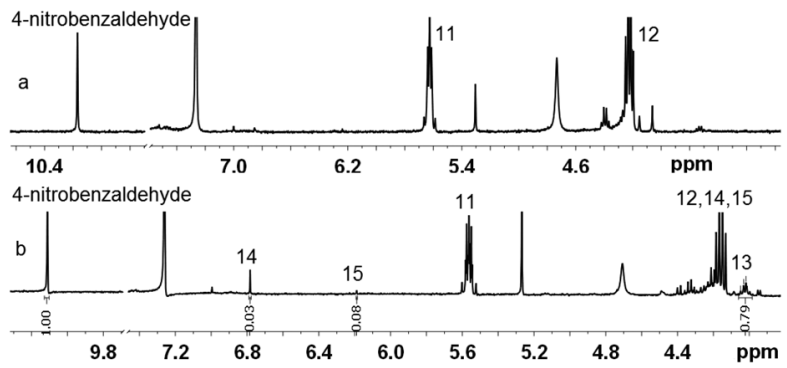

Fig. $3{ }^{1} \mathrm{H}$ NMR (400 MHz, $\mathrm{CD}_{2} \mathrm{Cl}_{2}, 298 \mathrm{~K}$ ) after reacting 11 and 12 for $4 \mathrm{~h}$ at $55{ }^{\circ} \mathrm{C}$ either in the presence of (a) nanoswitch [Cu(1)] $]^{+}$(CLOSE) or (b) nanoswitch $\left[\mathrm{Fe}(\mathrm{Cu}(1))_{2}\right]^{4+}$ (OPEN-II). 4-Nitrobenzaldehyde is the standard.

\section{Conclusions}

In conclusion, we have elaborated the new triangular nanoswitch 1 that may be toggled between open and closed forms by addition and removal of $\mathrm{Cu}^{+}$. Moreover, the closed switch $[\mathrm{Cu}(\mathbf{1})]^{+}$can be operated between a catalytically active dimeric (OPEN-II) and an inactive monomeric (CLOSE) form by alternate addition of $\mathrm{Fe}^{2+}$ and 4-N,N-dimethylaminoterpyridine. In the active form, the nanoswitch $\left[\mathrm{Fe}(\mathrm{Cu}(\mathbf{1}))_{2}\right]^{4+}=$ OPEN-II exposes the catalytically relevant $[\mathrm{Cu}(\text { phen })]^{+}$sites that are demonstrated to catalyse the cyclopropanation of $Z$-cyclooctene by ethyl diazoacetate.

In several ways, nanoswitch 1 mimics the mode of operation of the SARS-CoV 3C-like protease. Like the natural enzyme, the monomeric $\mathbf{1}$ is inactive because its catalytic machinery is frozen in the collapsed state, while it is catalytically active only as a homodimer.

The overall protocol serves as a show case for how a metalion signal ( $\mathrm{Fe}^{2+}$ input) can turn $\mathrm{ON}$ a process that is catalysed by a completely different metal ion. In principle, the same mode of operation should be applicable to hide any catalytically active metal ion in the heteroleptic complex $[\mathrm{M}(\mathbf{1})]^{n+}$ and expose its active site(s) after switching to the dimeric complex.

\section{Experimental procedures}

\section{General information}

All commercially available reagents were used without further purification and all solvents were distilled prior to use for column chromatography. We used silica gel 60 for thin-layer and column chromatography. The $400 \mathrm{MHz}{ }^{1} \mathrm{H}$ NMR spectra were recorded using the deuterated solvent as the lock and residual solvent as the internal reference. In ${ }^{1} \mathrm{H}$ NMR assignments, first, the chemical shift (in ppm) is given, followed, in brackets, by the multiplicity of the signal (s: singlet, d: doublet, t: triplet, dd: doublet of doublets, ddd: doublet of doublet of doublets, td: triplet of doublets, m: multiplet, bs: broad singlet), the value of the coupling constants in hertz $(\mathrm{Hz})$, the number of protons implied, and finally the assignment of the proton where ever possible. Anhydrous tetrahydrofuran (THF) was distilled over potassium and triethylamine was dried over calcium hydride. The melting points of solid compounds were not further corrected. IR spectra were recorded on a Perkin-Elmer FT-IR 1750. Electrospray ionisation mass spectra (ESI-MS) were recorded on a Thermo-Quest LCQ Deca. Microanalyses were performed on a Euro elemental analyser from EuroVector. The preparation and detailed characterisation of precursors 4-10 as well as full assignments for the nanoswitch system are provided in the ESI. $\dagger$

\section{Synthesis}

Nanoswitch 1 (OPEN-I). Phenanthroline 10 (210 mg, $283 \mu \mathrm{mol})$ and terpyridine 6 (128 $\mathrm{mg}, 284 \mu \mathrm{mol})$ were placed in a flask under an argon atmosphere. Then $30 \mathrm{~mL}$ of dry THF and $30 \mathrm{~mL}$ of dry TEA were added. After the solution had been 
deaerated for $1 \mathrm{~h}$ by purging with argon, $\mathrm{Pd}\left(\mathrm{PPh}_{3}\right)_{4}(50.0 \mathrm{mg}$, $43.3 \mu \mathrm{mol})$ was added. The reaction was heated at $65{ }^{\circ} \mathrm{C}$ for $18 \mathrm{~h}$, and then the solvents were removed in vacuum. The residue was dissolved in DCM and washed with water. The organic layer was dried over $\mathrm{Na}_{2} \mathrm{SO}_{4}$. The resulting solid obtained after evaporating the solvents was chromatographed over silica gel (10\% EtOAc in DCM) to furnish ligand 1 as a white solid ( $R_{\mathrm{f}}=0.7$ in DCM on neutral alumina). The ligand obtained after column chromatography was furthermore purified over Bio-Beads S-X8 using toluene as an eluent. The middle fraction contained the target compound. Yield: $130 \mathrm{mg}$ (122 $\mu \mathrm{mol}, 43 \%)$. MP: decomposition $>200{ }^{\circ} \mathrm{C}$. IR (KBr): v 3053, 2919, 2854, 2209, 1714, 1586, 1460, 1389, 1254, 994, 847, 793, 749, 618, $543 \mathrm{~cm}^{-1}$. ${ }^{1} \mathbf{H}$ NMR (400 $\left.\mathbf{~ M H z}, \mathbf{C D C l}_{3}\right): \delta=$ $2.05(\mathrm{~s}, 6 \mathrm{H}), 2.06(\mathrm{~s}, 6 \mathrm{H}), 2.33(\mathrm{~s}, 3 \mathrm{H}), 2.37(\mathrm{~s}, 3 \mathrm{H}), 2.41(\mathrm{~s}$, $3 \mathrm{H}), 6.95(\mathrm{~s}, 2 \mathrm{H}), 6.97(\mathrm{~s}, 2 \mathrm{H}), 6.98-7.00(\mathrm{~m}, 1 \mathrm{H}), 7.24-7.29$ (m, $3 \mathrm{H}), 7.33\left(\mathrm{dt},{ }^{3} J=7.6 \mathrm{~Hz},{ }^{4} J=1.6 \mathrm{~Hz} 1 \mathrm{H}\right), 7.48-7.50(\mathrm{~m}, 2$ H), $7.51\left(\mathrm{~d},{ }^{3} J=8.8 \mathrm{~Hz}, 1 \mathrm{H}\right), 7.55-7.57(\mathrm{~m}, 2 \mathrm{H}), 7.61\left(\mathrm{~d},{ }^{3} J=\right.$ $8.8 \mathrm{~Hz}, 1 \mathrm{H}), 7.68\left(\mathrm{~d},{ }^{3} J=8.4 \mathrm{~Hz}, 2 \mathrm{H}\right), 7.73\left(\mathrm{td},{ }^{3} J=7.6 \mathrm{~Hz},{ }^{4} J=\right.$ $2.0 \mathrm{~Hz}, 2 \mathrm{H}), 8.85\left(\mathrm{~d},{ }^{3} J=8.4 \mathrm{~Hz}, 2 \mathrm{H}\right), 8.13\left(\mathrm{~d},{ }^{3} J=8.0 \mathrm{~Hz}, 1 \mathrm{H}\right)$, $8.31(\mathrm{~s}, 1 \mathrm{H}), 8.45\left(\mathrm{ddd},{ }^{3} J=7.6 \mathrm{~Hz},{ }^{4} J=1.2 \mathrm{~Hz},{ }^{5} J=1.2 \mathrm{~Hz}\right.$, $2 \mathrm{H}), 8.68\left(\mathrm{ddd},{ }^{3} J=8.4 \mathrm{~Hz},{ }^{4} J=2.0 \mathrm{~Hz},{ }^{5} J=1.2 \mathrm{~Hz}, 2 \mathrm{H}\right), 8.70$ (s, $2 \mathrm{H}$ ) ppm. ${ }^{13} \mathbf{C}$ NMR (100 $\left.\mathbf{~ M H z}, \mathbf{C D C l}_{3}\right): \delta=20.1,20.5,21.1$ (2C), 21.2, 89.3, 90.3, 91.1, 91.9, 92.0, 93.4, 93.6, 97.6, 119.8, $121.1,122.9,123.3,123.5,124.1,124.9,125.0,125.2,125.5$, $125.6,125.7,126.5,126.7,126.8,127.5,128.0,128.2,128.3$, 128.5, 131.6, 131.8 (2C), 132.0, 132.4, 132.9, 133.8, 136.0, 136.1 (2C), 136.7, 137.0 (2C), 137.4, 137.6, 137.7, 139.0, 139.7, 144.6, 145.6, 149.0, 155.5, 160.3, 161.5 ppm. ESI-MS: $m / z(\%)=1065.9$ (100) $[\mathbf{1} \cdot \mathrm{H}]^{+} ;$calcd $\mathrm{m} / \mathrm{z}=1065.3$. Elemental analysis: $\mathrm{C}_{72} \mathrm{H}_{50} \mathrm{~N}_{5} \mathrm{Br} \cdot 0.33 \mathrm{DCM}$; Calcd: C, 79.46; H, 4.67; N, 6.41. Found: C, 79.25; H, 4.42; N, 6.38.

[Cu(1) $]^{+}$(CLOSE). Switch $1(2.57 \mathrm{mg}, 2.41 \mu \mathrm{mol})$ and $\left[\mathrm{Cu}\left(\mathrm{CH}_{3} \mathrm{CN}\right)_{4}\right] \mathrm{PF}_{6}(0.899 \mathrm{mg}, 2.41 \mu \mathrm{mol})$ were placed into an NMR tube and dissolved in $\mathrm{CD}_{2} \mathrm{Cl}_{2}$. The mixture was heated to $40{ }^{\circ} \mathrm{C}$ for a few seconds affording a reddish solution. The NMR was recorded without purification. Yield: quantitative. MP: $>300{ }^{\circ} \mathrm{C} .{ }^{\mathbf{1}} \mathbf{H}$ NMR $\left(\mathbf{4 0 0} \mathbf{~ M H z}, \mathbf{C D}_{2} \mathbf{C l}_{2}\right): \delta=1.05(\mathrm{~s}, 3 \mathrm{H}), 1.09$ (s, $3 \mathrm{H}), 1.63(\mathrm{~s}, 3 \mathrm{H}), 1.82(\mathrm{~s}, 3 \mathrm{H}), 1.88(\mathrm{~s}, 6 \mathrm{H}), 2.43(\mathrm{~s}, 3 \mathrm{H}), 4.48$ $(\mathrm{s}, 1 \mathrm{H}), 5.89(\mathrm{~s}, 1 \mathrm{H}), 6.28(\mathrm{~s}, 1 \mathrm{H}), 6.43(\mathrm{~s}, 1 \mathrm{H}), 6.67\left(\mathrm{~d},{ }^{3} J=\right.$ $4.8 \mathrm{~Hz}, 1 \mathrm{H}), 6.78\left(\mathrm{ddd},{ }^{3} J=7.6 \mathrm{~Hz},{ }^{3} J=4.8 \mathrm{~Hz},{ }^{4} J=1.2 \mathrm{~Hz}\right.$, $1 \mathrm{H}), 7.28\left(\mathrm{~d},{ }^{3} J=8.4 \mathrm{~Hz}, 2 \mathrm{H}\right), 7.30-7.39(\mathrm{~m}, 4 \mathrm{H}), 7.43-7.45$ (m, $2 \mathrm{H}), 7.58\left(\mathrm{~d},{ }^{3} J=8.4 \mathrm{~Hz}, 2 \mathrm{H}\right), 7.60-7.62(\mathrm{~m}, 2 \mathrm{H}), 7.64(\mathrm{~d}$, $\left.{ }^{3} J=7.6 \mathrm{~Hz}, 1 \mathrm{H}\right), 7.76\left(\mathrm{~d},{ }^{3} J=7.6 \mathrm{~Hz}, 1 \mathrm{H}\right), 7.78\left(\mathrm{~d},{ }^{3} J=8.4 \mathrm{~Hz}\right.$, $1 \mathrm{H}), 7.85\left(\mathrm{~d},{ }^{4} J=1.2 \mathrm{~Hz}, 1 \mathrm{H}\right), 7.87\left(\mathrm{td},{ }^{3} J=7.6 \mathrm{~Hz},{ }^{4} J=1.2 \mathrm{~Hz}\right.$ $1 \mathrm{H}), 8.03\left(\mathrm{~d},{ }^{4} J=1.2 \mathrm{~Hz}, 1 \mathrm{H}\right), 8.15\left(\mathrm{~d},{ }^{3} J=4.8 \mathrm{~Hz}, 1 \mathrm{H}\right), 8.18$ $\left(\mathrm{d},{ }^{3} J=8.8 \mathrm{~Hz}, 1 \mathrm{H}\right), 8.24\left(\mathrm{~d},{ }^{3} J=8.8 \mathrm{~Hz}, 1 \mathrm{H}\right), 8.65\left(\mathrm{~d},{ }^{3} J=8.4\right.$ $\mathrm{Hz}, 1 \mathrm{H}), 8.81(\mathrm{~s}, 1 \mathrm{H}) \mathrm{ppm} .{ }^{13} \mathrm{C}$ NMR (100 $\left.\mathbf{M H z}, \mathbf{C D}_{2} \mathbf{C l}_{2}\right): \delta=$ 18.6, 19.9, 20.0, 20.5, 20.7, 21.2, 21.2, 88.5, 89.0, 89.1, 89.6, 92.0, 93.6, 94.5, 96.9, 116.9, 120.9, 122.7, 123.0, 123.1, 123.2, $123.9,124.3,124.6,124.6,124.7,124.9,125.9,126.5,126.8$, $126.9,127.0,127.2,127.4,127.6,127.7,127.8,127.9,128.6$, $128.9,129.5,131.3,131.7,132.4,132.5,132.9,134.0,134.5$, 134.7, 135.0, 135.0, 136.4, 136.6, 137.0, 137.1, 137.4, 137.4, 138.3, 141.0, 141.0, 142.9, 144.4, 147.1, 148.1, 150.6, 152.7, 153.7, 153.8, 159.5, 159.9 ppm. ESI-MS: $m / z(\%)=1128.1(100)$
$[\mathrm{Cu}(\mathbf{1})]^{+} ;$calcd $\mathrm{m} / \mathrm{z}=1128.3$. Elemental analysis: $\mathrm{C}_{72} \mathrm{H}_{50} \mathrm{BrCuF}_{6} \mathrm{~N}_{5} \mathrm{P} \cdot 0.5 \mathrm{DCM}$; Calcd: C, 66.16; H, 3.91; N, 5.32. Found: C, 66.19; H, 4.11; N, 5.07.

Dimeric complex $\left[\mathrm{Fe}(\mathrm{Cu}(1))_{2}\right]^{4+} \quad($ OPEN-II). Switch 1 $(2.58 \mathrm{mg}, 2.42 \mu \mathrm{mol})$ and $\left[\mathrm{Cu}\left(\mathrm{CH}_{3} \mathrm{CN}\right)_{4}\right] \mathrm{PF}_{6}(903 \mu \mathrm{g}, 2.42 \mu \mathrm{mol})$ were put into an NMR tube, dissolved in $\mathrm{CD}_{2} \mathrm{Cl}_{2}$ and heated to $40{ }^{\circ} \mathrm{C}$ for few seconds affording a reddish solution. A solution of $\mathrm{Fe}\left(\mathrm{ClO}_{4}\right)_{2} \cdot 6 \mathrm{H}_{2} \mathrm{O}(439 \mu \mathrm{g}, 1.21 \mu \mathrm{mol})$ in $\mathrm{CD}_{3} \mathrm{CN}$ was added to the mixture and after that the mixture was heated for about 5 min at $40{ }^{\circ} \mathrm{C}$ affording a deep violet solution. The NMR was recorded without further purification. Yield: quantitative. MP: above $300{ }^{\circ} \mathrm{C} .{ }^{1} \mathbf{H}$ NMR (400 $\left.\mathbf{~ M H z}, \mathbf{C D}_{2} \mathbf{C l}_{\mathbf{2}}-\mathbf{C D}_{3} \mathbf{C N}=3: 1\right): \delta=$ $1.32(\mathrm{~s}, 6 \mathrm{H}), 1.76(\mathrm{~s}, 18 \mathrm{H}), 2.32(\mathrm{~s}, 6 \mathrm{H}), 2.33(\mathrm{~s}, 6 \mathrm{H}), 2.47$ (s, $6 \mathrm{H}), 6.90\left(\mathrm{~d},{ }^{3} \mathrm{~J}=7.6 \mathrm{~Hz}, 2 \mathrm{H}\right), 6.95(\mathrm{~s}, 4 \mathrm{H}), 6.96(\mathrm{~s}, 4 \mathrm{H})$, 7.07-7.10 (m, $8 \mathrm{H}), 7.21-7.25$ (m, $2 \mathrm{H}), 7.28-7.32(\mathrm{~m}, 2 \mathrm{H}), 7.45$ $\left(\mathrm{d},{ }^{3} \mathrm{~J}=7.6 \mathrm{~Hz}, 2 \mathrm{H}\right), 7.66-7.71(\mathrm{~m}, 8 \mathrm{H}), 7.78\left(\mathrm{~d},{ }^{3} \mathrm{~J}=8.0 \mathrm{~Hz}\right.$, $2 \mathrm{H}), 7.80-7.85(\mathrm{~m}, 2 \mathrm{H}), 7.92\left(\mathrm{~d},{ }^{3} \mathrm{~J}=8.4 \mathrm{~Hz}, 4 \mathrm{H}\right), 8.04\left(\mathrm{~d},{ }^{3} \mathrm{~J}=\right.$ $8.8 \mathrm{~Hz}, 2 \mathrm{H}), 8.07\left(\mathrm{~d},{ }^{3} J=8.8 \mathrm{~Hz}, 2 \mathrm{H}\right), 8.15\left(\mathrm{~d},{ }^{3} J=7.6 \mathrm{~Hz}, 4 \mathrm{H}\right)$, $8.58\left(\mathrm{~d},{ }^{3} \mathrm{~J}=8.0 \mathrm{~Hz}, 2 \mathrm{H}\right), 8.70(\mathrm{~s}, 2 \mathrm{H}), 8.80(\mathrm{~s}, 4 \mathrm{H}) \mathrm{ppm}$. ${ }^{13} \mathrm{C}$ NMR (100 MHz, $\left.\mathbf{C D}_{2} \mathbf{C l}_{2}-\mathbf{C D}_{3} \mathbf{C N}=3: 1\right): \delta=19.6,19.9$, 21.0, 21.1, 21.1, 89.3, 89.4, 90.3, 90.8, 93.2, 95.2, 97.1, 97.6, $122.3,123.4,123.9,124.2,124.5,124.9,125.2,125.3,125.6$, $125.7,126.5,126.9,127.6,127.8,128.1,128.2,128.2,128.3$, $128.8,129.4,132.2,132.3,132.3,132.7,132.9,132.9,135.2$, $135.7,135.9,136.2,137.1,138.2,138.9,138.9,139.1,140.0$, $141.2,142.2,143.4,153.1,157.2,160.1,160.3,161.5$ ppm. Elemental analysis: $\mathrm{C}_{144} \mathrm{H}_{100} \mathrm{Br}_{2} \mathrm{Cl}_{2} \mathrm{Cu}_{2} \mathrm{~F}_{12} \mathrm{FeN}_{10} \mathrm{O}_{8} \mathrm{P}_{2} \cdot 3 \mathrm{CH}_{2} \mathrm{Cl}_{2}$. $\mathrm{CH}_{3} \mathrm{CN}$; Calcd: C, 57.77; H, 3.55; N, 4.97. Found: C, 57.47; $\mathrm{H}, 3.52 ; \mathrm{N}, 5.32$.

\section{Model catalysis}

Catalytic cyclopropanation reactions were performed on a $10 \mathrm{mM}$ scale. A mixture of $Z$-cyclooctene, ethyl diazoacetate and $\left[\mathrm{Cu}\left(\mathrm{CH}_{3} \mathrm{CN}\right)_{4}\right] \mathrm{PF}_{6}$ was heated at $55{ }^{\circ} \mathrm{C}( \pm 0.1)$ for $4 \mathrm{~h}$ in an NMR tube in a HAAKE-N2 thermostat. The literature known addition adducts 13, 14 and 15 were characterised by ${ }^{1} \mathrm{H}$ NMR. The above reaction was also carried out by heating an equimolar mixture of $Z$-cyclooctene and ethyl diazoacetate in the presence of $10 \mathrm{~mol} \%$ of $[\mathrm{Cu}(2)] \mathrm{PF}_{6}$ to mimic the situation in $\left.\left[\mathrm{Fe}(\mathrm{Cu}(\mathbf{1}))_{2}\right)\right]^{4+}$.

\section{Catalysis experiments using the nanoswitch}

The catalytic reaction with the nanoswitch was probed at a similar scale using the same conditions as described above. Equivalent amounts of $Z$-cyclooctene $(677 \mu \mathrm{mg}, 6.14 \mu \mathrm{mol})$ and ethyl diazoacetate $(701 \mu \mathrm{mg}, 6.14 \mu \mathrm{mol})$ were mixed with $10 \mathrm{~mol} \%$ of nanoswitch 1 (654 $\mu \mathrm{mg}, 0.614 \mu \mathrm{mol})$ and $\left[\mathrm{Cu}\left(\mathrm{CH}_{3} \mathrm{CN}\right)_{4}\right] \mathrm{PF}_{6}(229 \mu \mathrm{mg}, 0.614 \mu \mathrm{mol})$. With the closed form of the nanoswitch, i.e. $[\mathrm{Cu}(\mathbf{1})] \mathrm{PF}_{6}$, no cyclopropanated product 13 was formed in detectable amount. However, upon addition of 0.5 equivalent of $\mathrm{Fe}\left(\mathrm{ClO}_{4}\right)_{2}(111 \mu \mathrm{mg}, 0.306 \mu \mathrm{mol})$ with respect to nanoswitch $\mathbf{1}$, the dimeric form $\left[\mathrm{Fe}(\mathrm{Cu}(\mathbf{1}))_{2}\right]^{4+}$ should form. Indeed, after heating the mixture for $4 \mathrm{~h}$ at $55{ }^{\circ} \mathrm{C}$ cyclopropane $\mathbf{1 3}$ was afforded. 


\section{Acknowledgements}

We are grateful to the Deutsche Forschungsgemeinschaft and the Universität Siegen for financial support.

\section{Notes and references}

1 (a) C. Dietrich-Buchecker, M. C. Jimenez-Molero, V. Sartor and J.-P. Sauvage, Pure Appl. Chem., 2003, 75, 1383; (b) V. Balzani, A. Credi, S. Silvi and M. Venturi, Chem. Soc. Rev., 2006, 35, 1135; (c) E. R. Kay, D. A. Leigh and F. Zerbetto, Angew. Chem., Int. Ed., 2007, 46, 72; (d) S. Saha and J. F. Stoddart, Chem. Soc. Rev., 2007, 36, 77; (e) M. von Delius and D. A. Leigh, Chem. Soc. Rev., 2011, 40, 3656; (f) A. Coskun, M. Banaszak, R. D. Astumian, J. F. Stoddart and B. A. Grzybowski, Chem. Soc. Rev., 2012, 41, 19; (g) K. Ariga, T. Mori, S. Ishihara, K. Kawakami and J. P. Hill, Chem. Mater., 2014, 26, 519.

2 (a) B. L. Feringa, R. A. V. van Delden, N. Koumura and E. M. Geertsema, Chem. Rev., 2000, 100, 1789; (b) Molecular switches, ed. B. L. Feringa and W. R. Browne, Wiley-VCH, Weinheim, 2011; (c) X. Su, T. F. Robbins and I. Aprahamian, Angew. Chem., Int. Ed., 2011, 50, 1841; (d) H. Li, A. C. Fahrenbach, A. Coskun, Z. Zhu, G. Barin, Y.-L. Zhao, Y. Y. Botros, J.-P. Sauvage and J.-F. Stoddart, Angew. Chem., Int. Ed., 2011, 50, 6782; (e) A. C. Fahrenbach, S. C. Warren, J. T. Incorvati, A.-J. Avestro, J. C. Barnes, J. F. Stoddart and B. A. Grzybowski, Adv. Mater., 2013, 25, 331; (f) X. Su and I. Aprahamian, Chem. Soc. Rev., 2014, 43, 1963; (g) S. F. M. van Dongen, S. Cantekin, J. A. A. W. Elemans, A. E. Rowan and R. J. M. Nolte, Chem. Soc. Rev., 2014, 43, 99.

3 (a) Y. Liu, A. H. Flood, P. A. Bonvallet, S. A. Vignon, B. H. Northrop, H.-R. Tseng, J. O. Jeppesen, T. J. Huang,
B. Brough, M. Baller, S. Magonov, S. D. Solares, W. A. Goddard, C.-M. Ho and J. F. Stoddart, J. Am. Chem. Soc., 2005, 127, 9745; (b) R. Eelkema, M. M. Pollard, J. Vicario, N. Katsonis, B. S. Ramon, C. W. M. Bastiaansen, D. J. Broer and B. L. Feringa, Nature, 2006, 440, 163; (c) V. N. Vukotic and S. J. Loeb, Chem. Soc. Rev., 2012, 41, 5896; (d) J. E. Beves, V. Blanco, B. A. Blight, R. Carrillo, D. M. D'Souza, D. Howgego, D. A. Leigh, A. M. Z. Slawin and M. D. Symes, J. Am. Chem. Soc., 2014, 136, 2094.

4 (a) F. Würthner and J. Rebek Jr., Angew. Chem., Int. Ed., 1995, 34, 446; (b) P. Thordarson, E. J. A. Bijsterveld, A. E. Rowan and R. J. M. Nolte, Nature, 2003, 424, 915; (c) J. Wang and B. L. Feringa, Science, 2011, 331, 1429; (d) O. B. Berryman, A. C. Sather, A. Lledó and J. Rebek Jr., Angew. Chem., Int. Ed., 2011, 50, 9400; (e) V. Blanco, A. Carlone, K. D. Hänni, D. A. Leigh and B. Lewandowski, Angew. Chem., Int. Ed., 2012, 51, 5166; (f) U. Lüning, Angew. Chem., Int. Ed., 2012, 51, 8163; $(g)$ B. Lewandowski, G. De Bo, J. W. Ward, M. Papmeyer, S. Kuschel, M. J. Aldegunde, P. M. E. Gramlich, D. Heckmann, S. M. Goldup, D. M. D'Souza, A. E. Fernandes and D. A. Leigh, Science, 2013, 339, 189.

5 (a) M. Schmittel, S. De and S. Pramanik, Angew. Chem., Int. Ed., 2012, 51, 3832; (b) M. Schmittel, S. Pramanik and S. De, Chem. Commun., 2012, 48, 11730.

6 J. Shi, J. Sivaraman and J. Song, J. Virol., 2008, 82, 4620.

7 M. L. Saha and M. Schmittel, Org. Biomol. Chem., 2012, 10, 4651.

8 M. Schmittel, V. Kalsani, R. S. K. Kishore, H. Cölfen and J. W. Bats, J. Am. Chem. Soc., 2005, 127, 11544.

9 M. L. Saha, S. De, S. Pramanik and M. Schmittel, Chem. Soc. Rev., 2013, 42, 6860.

10 (a) S. De, K. Mahata and M. Schmittel, Chem. Soc. Rev., 2010, 39, 1555; (b) M. L. Saha, S. Neogi and M. Schmittel, Dalton Trans., 2014, 43, 3815. 